\title{
Mass Layoffs and CEO Turnover
}

\section{SHERRILYN M. BILLGER and KEVIN F. HALLOCK}

\begin{abstract}
We investigate the relationship between layoff announcements and CEO turnover over a 31-year period. We find that layoffs significantly increase CEO turnover in the following year, and, in some time periods, CEO changes are strongly positively associated with layoff announcements two years earlier. We proceed to show how this relationship has changed over time, and offer several possible explanations. Finally, we find strong evidence that layoffs that are associated with negative stock price reactions are much more likely to lead to CEO turnover than those associated with positive stock price reactions, especially in the earlier years in our sample.
\end{abstract}

IT IS NOT CLEAR WHETHER JOB LOSS ANNOUNCEMENTS AND CEO TURNOVER SHOULD BE POSITIVELY OR NEGATIVELY CORRELATED. While positive relative stock returns certainly signal "good" performance, the role of mass layoffs is not similarly obvious. For example, a major layoff announcement can be a positive sign that a struggling company is serious about reorganization and making efforts to improve profitability. On the other hand, mass layoffs could also represent the last-ditch efforts by CEOs to keep their jobs. As job loss announcements and executive turnover represent relatively high-stakes outcomes, we focus on the relationship between mass job loss announcements and top management turnover in an attempt to explore these ideas more thoroughly. This project is a careful consideration of mass layoffs and their specific, although likely varied, impacts on a central component of the executive labor market, namely turnover. Indeed, some CEOs are expected to lay off employees in certain situations, and we attempt to

* The authors' affiliations are, respectively, Department of Economics, Illinois State University, Campus Box 4200, Normal, IL 61790, and Departments of Economics and Finance, and Institute of Labor and Industrial Relations, University of Illinois at Urbana-Champaign and NBER. E-mail: smbillg@ilstu.edu and hallock@uiuc.edu. We are grateful to Lee Alston, David Balan, John Deke, Henry Farber, Marianne Ferber, Wally Hendricks, John Johnson, David Levine, Daniel Morillo, Ralph Walkling, Michael Weisbach, Karen Wruck, and three anonymous referees for their helpful suggestions. Cecily Fluke and Kevin J. Murphy kindly provided some of the information on CEOs that we used in computing management turnover. Some other data were obtained from EXECUCOMP, which are available for a fee from Standard \& Poor's. We also thank the Industrial Relations Section at Princeton University, the Institute of Labor and Industrial Relations, and the Office of Research in the College of Business at the University of Illinois for support. 
determine whether CEOs are acting as their boards expect (and want), or if the layoffs signal the ultimate failure of the executive with that firm.

There is currently a great deal of interest in the layoffs and their consequences for both employees and for firms. ${ }^{1}$ Work on the effects on workers has continued for some time. An excellent recent example in this area is that by Farber (2003). In the past few years, economists have turned their attention to outcomes for firms. This work has included examples that study the relationship between job loss and establishment (Cappelli, 2000) or firm performance (Dial and Murphy, 1995), job loss announcements and stock prices (Farber and Hallock, 2003), or more generally, the causes and consequences of "downsizing" (Baumol, Blinder, and Wolff, 2003).

One of the important outcomes for firms is related to the CEO. Using a much smaller sample than that which we use here, Hallock (1998) investigated the relationship between layoff announcements in large firms, and CEO compensation in those same firms (described in succeeding discussions). We consider it also interesting to investigate another important aspect of the CEO labor market: turnover. CEOs have a great deal of discretion in setting the strategy for their firms, and because it is perfectly reasonable for them to want to stay in their positions, they are likely to manage firms in ways that should allow them to stay in office.

This paper will therefore empirically investigate whether CEOs are rewarded (by keeping their jobs) or punished (as measured by turnover) for directing mass layoffs of workers. We will also study whether this relationship changes over time, and whether it is independent of the reaction of individual firm stock prices to layoff announcements.

We begin by documenting the relationship between firm performance and executive turnover using one data set covering a longer time period than contained in previous studies. We also attempt to detect possible changes in turnover, and the performance/turnover relationship from 1970 through 2000. We find that for the firms in our sample, CEO turnover has increased over time, but the relationship between turnover and stock returns has been relatively consistent. We then examine the impact of job loss announcements on the likelihood of turnover. Depending on the time period in question, conditional upon firm and CEO characteristics, we find some evidence that layoff announcements are positively associated with the probability a CEO will leave the firm.

Layoffs are positively associated with the probability of CEO turnover throughout all decades in our data, but the relationship varies in significance. We find some significant evidence that job loss announcements negatively

${ }^{1}$ We are grateful to a referee for several suggestions that have helped us to motivate the paper. 
affected executive turnover during the 1970s. That is, CEOs were less likely to separate from firms after making layoff announcements. In the 1980s, however, any layoff increases the likelihood of a CEO change two years in the future by nearly 8 percent, depending on the empirical specification. This relationship is not significantly different from zero in the 1990s, however. We then discuss possible explanations for these findings, including an examination of the specific characteristics of the layoffs. For instance, the stated reasons for layoffs have changed over time, with increasingly fewer instances of "low demand" and more of "efficiency" reasons. This could affect the perceptions of whether layoffs are indicators of problems or improvements, thus impacting top management turnover.

Because it seems reasonable to categorize the layoffs into whether the market perceived them as "good" news or as "bad" news, we also examine whether the short-term stock price reaction to layoff announcements has any effect on these relationships. We find strong evidence that layoffs that are associated with negative stock price reactions are much more likely to lead to CEO turnover than layoffs associated with positive stock price reactions.

This paper proceeds as follows. In the first section, we discuss previous literature on the relationship between firm performance and executive turnover, and then focus on job loss announcements. We briefly describe the previous work on CEO turnover in large firms, as well as the effects of job loss announcements on firms. The second section identifies the data we use in our study. These data include detailed information on firms, CEOs, and layoff announcements, and are compiled from a variety of sources. In the third section, we provide empirical results for the relationship between firm performance and turnover during the extensive time period covered by our data. The next section examines job loss announcements, and documents the estimated relationship between such announcements and CEO turnover. In the fifth section, we discuss possible explanations for our results on the relationship between mass layoff announcements and management turnover, including an examination of reported reasons. Section six is an examination of whether the short-term stock price reaction to job loss announcements can help explain CEO turnover. Concluding remarks and suggestions for future research are presented in the last section.

\section{Recent Work on Management Turnover and Job Loss Announcements}

There is a substantial literature on the effects of firm performance on management turnover in the United States and in other countries, beginning 
with Coughlan and Schmidt (1985), who showed that the probability of management turnover declines as stock price improves. Later, researchers also began to study the effects of job loss announcements on firm outcomes. We will describe previous studies that focus on either executive turnover or mass layoffs, continuing with a discussion of how we will extend the literature by combining these issues.

Firm Performance and CEO Turnover. ${ }^{2}$ Simple agency theory is often used to describe the compensation of top managers of firms. That is, compensation plans are designed to align the interests of self-interested managers with those of the shareholders (Berle and Means, 1932 and Jensen and Meckling, 1976). The same ideas can be extended to turnover. If managers are earning more than their opportunity cost, the threat of firing provides incentives to align the interests of shareholders with the managers.

Although we know from Vancil (1987), Weisbach (1988), and others that top managers of firms are rarely publicly fired, there does seem to be a strong relationship between the performance of a firm and the probability that the top manager will turnover. ${ }^{3}$ A great deal of attention has been paid to the link between CEO pay and company performance, and this can be extended to CEO turnover. If a CEO performs poorly, he loses his job. As more data on top executives are now available, many of the analyses that originally studied the link between pay and performance switched to studying the link between CEO turnover and firm performance. Several of the most influential of these studies are discussed here.

Warner, Watts, and Wruck (1988) examine the link between lagged stock returns and CEO turnover. They use a sample of top management changes from 1963 through 1978. They find that as firm performance declines, the probability of a change in top management increases. They do point out, however, that the performance must be unusually high or low to detect these differences empirically. Weisbach (1988) uses data on the characteristics of boards of directors, firms, and changes in the CEO for several hundred large firms from the 1970s through the early 1980s. Consistent with Warner, Watts, and Wruck (1988), he finds a connection between poor firm performance and CEO resignations that remains after controlling for industry, firm size, and firm ownership. ${ }^{4}$ Additional work by Kaplan (1994a,b) and Conyon (1998) explored CEO turnover in other countries.

\footnotetext{
${ }^{2}$ This subsection is based, in part, on Hallock and Murphy (1999).

${ }^{3}$ See Coughlan and Schmidt (1985), Gilson (1989), Denis and Denis (1995), Hadlock and Lumer (1997), Mikkelson and Partch (1997), Parrino (1997) and Huson, Parrino, and Sparks (1998).

${ }^{4}$ This result is stronger in firms dominated by outside directors than for firms dominated by insiders.
} 
Job Loss Announcements and Firm Outcomes. There is a growing literature on the effects of job loss announcements on firm outcomes, including firm stock price and CEO pay, and our work thus adds to the general discovery of the relationship between job loss announcements and firm outcomes. Hallock (1998) investigates the relationship between job loss announcements and CEO pay using a sample of large U.S. firms and data from 1987 to 1995 . He finds that firms that announce layoffs in the previous year pay their CEOs more, and give their top managers larger percentage raises than firms which do not have at least one layoff announcement in the previous year. He also finds, though, that the likelihood of a firm announcing a layoff in a given year is related to one of the most important correlates of CEO pay-firm size (as measured, for example, by the log of the market value of equity). After controlling for observed and unobserved characteristics of the firm, the CEO's pay premium for laying off workers disappears. ${ }^{5}$

Farber and Hallock (2004) study the short-term stock price reaction to job loss announcements using data from 1970 to 1999. They find clear evidence that the share price reaction to job loss announcements has become less negative over time. A potential reason for this is that the fraction of job loss announcements related to "deficient demand" reasons (which would tend to drive prices down) has decreased relative to the fraction resulting from "efficiency" reasons (which would likely be better news for stock prices) over time. However, the authors find that most of the changes in share price reactions to job loss announcements over the sample remain unexplained.

\section{Data}

The data for this paper are collected from several distinct sources. The data on management turnover from 1970 to 1991 are from Forbes magazine's Annual Compensation Issues and the 1992-2000 data are from Standard \& Poor's EXECUCOMP. We have two sources of accounting and financial information for the firms. We collected annual accounting and other financial information from Standard and Poor's COMPUSTAT and compute annual rates of return to firms' common stock from data from the Center for Research in Securities Prices (CRSP) at the University of Chicago. Finally, the data on job loss announcements are collected from Wall Street Journal abstracts and articles.

\footnotetext{
${ }^{5}$ Hallock (1998) also finds a weak negative stock price reaction to layoff announcements. Farber and Hallock (2004) provide a summary of papers that find a similar relationship.
} 
TABLE 1

Sample Means by Layoff Status

\begin{tabular}{|c|c|c|c|c|}
\hline & All firms & $\begin{array}{c}\text { No layoff } \\
\text { announcements } \\
\text { in year } t\end{array}$ & $\begin{array}{l}\text { At least one } \\
\text { Layoff in year } t\end{array}$ & $\begin{array}{c}\text { Absolute } \\
\text { value of } \\
t \text { statistic }\end{array}$ \\
\hline \multicolumn{5}{|l|}{ CEO turnover } \\
\hline New CEO in year $t+1$ & $\begin{array}{r}0.122 \\
(0.004)\end{array}$ & $\begin{array}{l}0.118 \\
(0.004)\end{array}$ & $\begin{array}{c}0.143 \\
(0.010)\end{array}$ & 2.267 \\
\hline \multicolumn{5}{|l|}{ CEO characteristics } \\
\hline Age & $\begin{array}{l}57.697 \\
(0.068)\end{array}$ & $\begin{array}{l}57.578 \\
(0.073)\end{array}$ & $\begin{array}{l}57.824 \\
(0.182)\end{array}$ & 0.745 \\
\hline Tenure with firm & $\begin{array}{r}25.338 \\
(0.126)\end{array}$ & $\begin{array}{c}25.292 \\
(0.134)\end{array}$ & $\begin{array}{l}25.647 \\
(0.359)\end{array}$ & 0.925 \\
\hline Tenure as CEO & $\begin{array}{r}7.862 \\
(0.075)\end{array}$ & $\begin{array}{l}8.031 \\
(0.082)\end{array}$ & $\begin{array}{l}6.731 \\
(0.187)\end{array}$ & 6.372 \\
\hline \multicolumn{5}{|l|}{ Firm characteristics } \\
\hline $\begin{array}{l}\text { Market value of equity }{ }^{a} \\
\text { (millions) }\end{array}$ & $\begin{array}{r}4741.334 \\
(122.129)\end{array}$ & $\begin{array}{l}4324.67 \\
(120.98)\end{array}$ & $\begin{array}{l}7531.80 \\
(468.47)\end{array}$ & 6.629 \\
\hline $\begin{array}{l}\text { Total number of } \\
\text { employees }^{b} \text { (thousands) }\end{array}$ & $\begin{array}{l}37.555 \\
(0.663)\end{array}$ & $\begin{array}{l}31.494 \\
(0.575)\end{array}$ & $\begin{array}{l}77.497 \\
(3.122)\end{array}$ & 14.494 \\
\hline Number of unique firms & 500 & & & \\
\hline Number of observations & 8690 & 7561 & 1129 & \\
\hline
\end{tabular}

The data were gathered from Wall Street Journal abstracts, ComPustat, CRSP, and Forbes.

Standard errors appear in parentheses.

${ }^{a}$ in inflation-adjusted 1990 dollars.

${ }^{b}$ The number of observations for this variable is 8569 .

CEOs. Kevin J. Murphy and Cecily Fluke provided the information on CEOs that was used to construct our basic measures of CEO turnover for the years 1970-1991. In both cases, the data were originally collected by Forbes magazine, and details on CEOs and their pay structure are published in the Forbes' annual compensation issue for a set of roughly 800 firms per year. ${ }^{6}$ For the remaining years, we use Standard \& Poor's ExECUCOMP to calculate turnover. Our base sample includes all firms in the sample from 1970 to 2000.

We display descriptive statistics from these samples in the top panel of Table 1. Our measure of CEO turnover is equal to 1 if there is a change in the name of the CEO in the next year. ${ }^{7}$ We see in Table 1 that, on average, 12.2 percent of firms have a new CEO in a given year. Figure 1 plots the

\footnotetext{
${ }^{6}$ A wide variety of papers have used Forbes data to research CEO pay and turnover (e.g. Jensen and Murphy, 1990). More recent papers on CEO pay have not used Forbes data since Forbes has not systematically reported the valuation of stock options over time (see Hall and Liebman, 1998 for a recent example of a paper that does value options). However, since the focus of this paper is on turnover and not pay, this data problem is not an issue for us.

${ }^{7}$ There may be some instances, especially with the Forbes data, where a CEO will join and depart (perhaps an "interim" CEO) in the same fiscal year. Given our data, we will miss these occurrences.
} 
FIGURE 1

CEO Turnover by Year

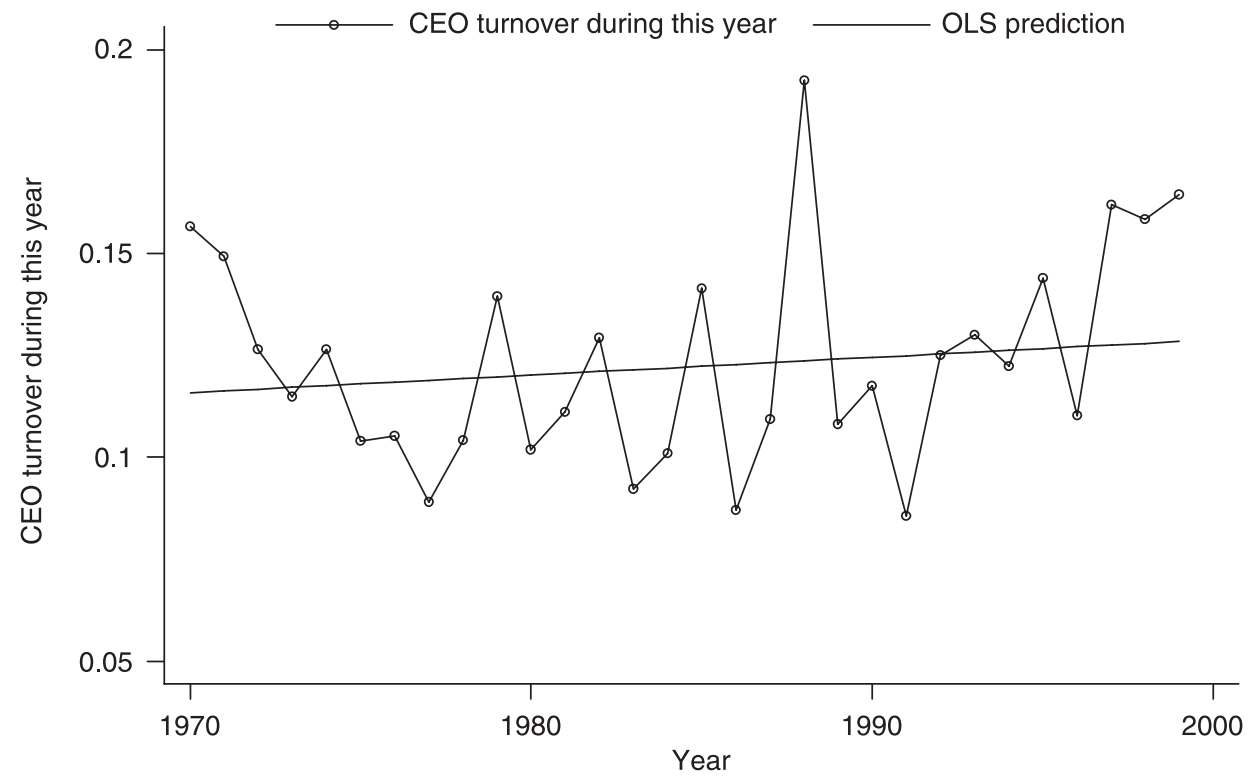

mean of the turnover variable for each year from 1970 to 2000 . The figure shows that the rate of turnover has increased somewhat over time, but is quite variable as well. Also plotted in Figure 1 is a least-squares line fitted through the annual average turnover data that further highlights the increase over time. Table 1 also reports that the average firm's CEO is 58 years old, has been with his firm for 25 years, and has been CEO for 8 years. These characteristics are consistent with a host of previous studies.

Firms. COMPUSTAT and Center for Research in Security Prices "CRSP" are the sources for the annual firm characteristic data. The second part of Table 1 reports the mean market value of the firm (calculated as the price per share times the total number of shares, reported in millions of 1990 dollars), and the average number of employees for each firm (reported in thousands) from 1970 through 2000. The averages for these variables for the sample period were $\$ 4.74$ billion and 37,555 , respectively.

Layoff Announcements. The layoff data were collected by first reading the abstracts from the Wall Street Journal index, and then by reading the fulllength articles in the Wall Street Journal (as described in succeeding discussion). We created our job loss announcement sample by identifying each firm that 
ever existed in the Fortune 500 from 1970-2000. This generated a list of 1849 different firm names over the sample period. For each year, we then searched for any record of a job loss announcement within the company name sections of each of the Wall Street Journal indexes over the sample period. When an announcement was found, we recorded the date of the announcement, and where available, several other pieces of information (discussed further) including the number of workers involved in the layoff, the "reason" for the layoff, whether it was temporary or permanent, and whether it involved a foreign subsidiary. The reason we used a paper source such as the Wall Street Journal index and not an electronic source is because, at the time the data were collected, no electronic source would allow us to search as far back as 1970, and we wanted to use as consistent a sample as possible throughout the entire time period. ${ }^{8}$ Because we felt that we did not have sufficiently detailed information at this point, we returned to the more than 4000 individual job loss announcements and read the full-length articles on each. For example, when reading only the abstracts, we were able to identify "reasons" for layoffs for just over two-thirds of the observations. However, after reading the full-length articles, we were able to do this for greater than 97 percent of the observations. The data collection on layoffs alone took roughly 3000 hours.

If in a given year, no articles were found for a given firm in the sample, that firm was assigned zero layoff announcements. There are certainly potential problems with using data from a source such as the Wall Street Journal (see Thompson, Olsen, and Dietrich, 1987). For example, it may be the case that either not all RIFs are announced in the Wall Street Journal, or that the journal chooses not to report all events. However, we believe that most job loss events in these firms are reported in the Wall Street Journal index for at least two reasons. First, because the basic sample is the Fortune 500 - roughly the largest and most visible firms in the United States - it is reasonable to assume that the Wall Street Journal would cover most news stories about these firms. Secondly, there is substantial evidence of very small job loss announcements reported (e.g., as few as eight or ten workers). The fraction of firms with at least one layoff per year has varied over time, but generally follows the state of the economy, as seen in Figure 2. See Hallock (2003) for much more detail on the job loss announcement data.

Clearly, the job loss announcement data can be used at the level of each announcement. In fact, our base sample contains more than 4200 individual announcements. However, because there can be multiple job loss announcements in a given firm in a given year, and our CEO turnover data

${ }^{8}$ The tabulations we report and use in this paper compare favorably with Hallock (1998) who has completed the largest previous study (using data from 1987-1995) using an electronic source. 
FIGURE 2

Fraction Firms With LAYOFF AND Unemp Rate

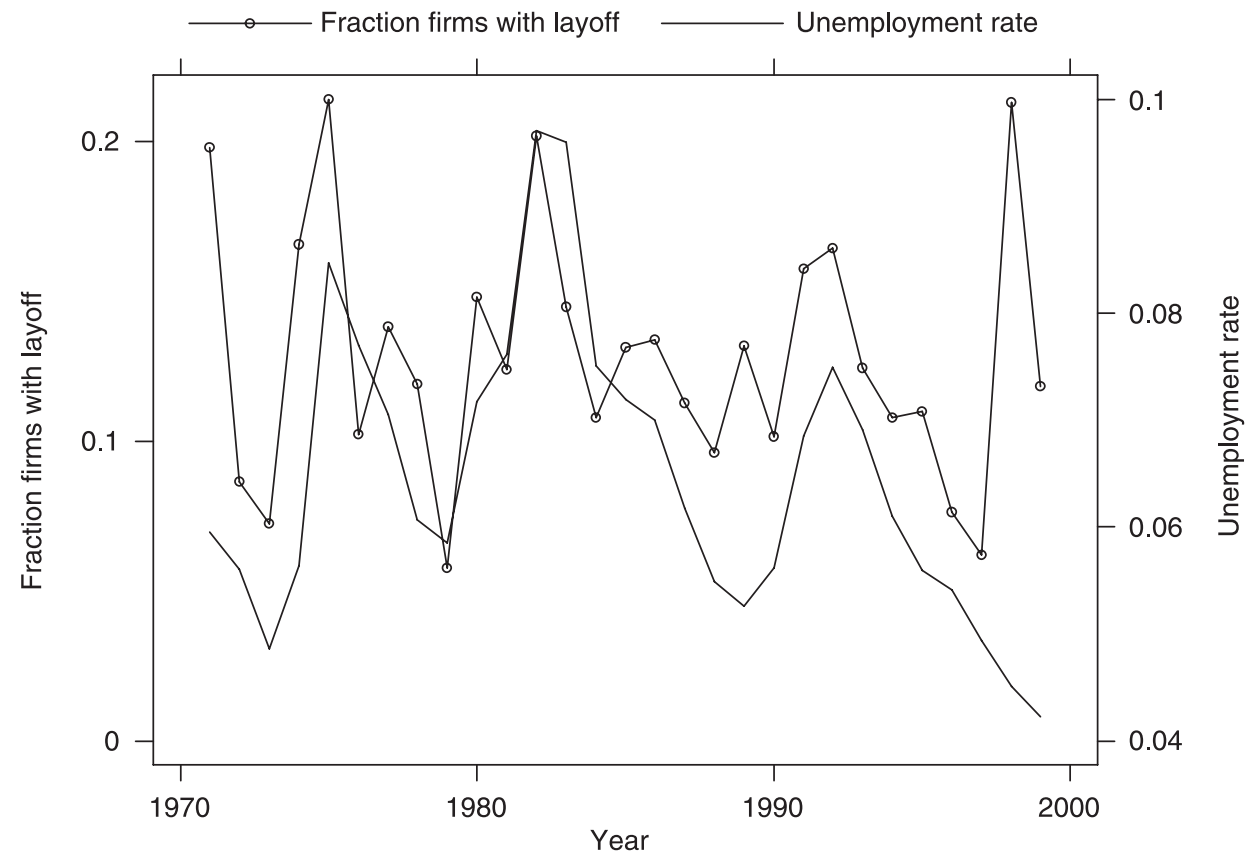

are annual, we primarily focus on aggregate data within a fiscal year. ${ }^{9}$ That is, our unit of observation is a firm-year. Table 1 reveals that of the 8690 firmyears in our combined CEO/firm/layoff sample, 1129 (or approximately 13 percent) included at least one job loss announcement. ${ }^{10}$

As shown in the middle two columns in Table 1, some of the basic characteristics of CEOs and firms vary somewhat by whether there is at least one layoff in the firm. For example, firms that have at least one layoff are more likely to have a new CEO in the following year (14.3 percent of firms versus 11.8 percent). Similarly, firms with at least one layoff in the current year have CEOs who have about 1.3 fewer years seniority in that position. In addition, firms with at least one layoff announcement in the previous year are larger. For example, the average market value of the firm

\footnotetext{
${ }^{9}$ All data are reported for fiscal years.

${ }^{10}$ Although we started with 1849 different firm names from each firm that ever existed in the Fortune 500 in any year from 1970-2001, it is clear from Table 1 that we only have complete information on 500 firms. This is because of two reasons. First, firms have name changes over time so that a unique firm may be associated with multiple firm names over time. The second reason is that not all firms for which we have data on layoff announcements have matching information in the Forbes, EXECUCOMP, COMPUSTAT, or CRSP samples.
} 
for the group with at least one layoff is almost double the average for the group with no layoff during the year. The same is true for the number of employees in the firm. We investigate these relationships more carefully in further discussions. We now turn to basic relationships between firm performance and management turnover.

\section{Firm Performance and Management Turnover}

Baseline Specifications. As found in previous studies, we expect that poor firm performance increases the probability that a CEO will turnover, all else being equal. It is important to confirm that our basic specifications are similar to those of other authors for a few different reasons. First, we want to be sure that the specifications can be compared to other work. Second, this baseline work will help us consider important measures of firm performance that will be important to other parts of the paper. We use stock returns to measure performance, which also allows for easy comparison to similar studies. We include both firm and market returns in order to control for relative performance. ${ }^{11}$ The motivation behind using relative performance is that CEOs are not extensively affected by random factors. For instance, an economy-wide recession should not, in and of itself, cause the top manager to be dismissed. Antle and Smith (1986) focus on 39 firms from 1947 to 1977, and find that a firm's performance relative to other firms in the same industry is significantly related to CEO compensation. This is true for return on assets, but not for stock returns. Gibbons and Murphy (1990) use data for 1049 companies from 1974 to 1986 to examine the role of relative performance in determining top management compensation and turnover. They find that greater own-firm returns increase compensation and decrease the likelihood of a CEO change, while market returns decrease compensation and increase the probability of turnover.

In addition to controls for relative firm performance, we include the log of the market value of equity as a measure of firm size. Finally, CEO characteristics are essential to estimating the probability of turnover. To this end we include controls for age, tenure with the firm, and tenure as CEO. ${ }^{12}$ The

\footnotetext{
${ }^{11}$ Market returns were constructed as average returns across all firms in the sample for that year, excluding the relevant firm. Note that because of this construction, controlling for year effects (with indicator variables) is problematic. This is because (except for the exclusion of the single relevant firm each time) the measure of market return is almost perfectly predicted by a year indicator variable.

${ }^{12}$ In results not reported here, we also included an indicator variable equal to one in the CEO's first 2 years of tenure as CEO. This had no meaningful impact on the performance variables.
} 
full specification is then a logit regression of the probability of CEO turnover on a set of characteristics of the firm and the CEO:

$$
\begin{gathered}
\text { Probability of CEO turnover }=F(\beta \text { (own returns })_{i t}+\delta(\text { market returns })_{t} \\
\left.+\gamma \ln (\text { market value })_{i t}+\phi(\text { CEO characteristics })+\alpha_{i}+\varepsilon_{i t}\right),
\end{gathered}
$$

where $i$ represents firms, $t$ represents years, and CEO turnover equals 1 in the CEO's last year (year $t$ ) and equals 0 otherwise. $F(\bullet)$ represents the logistic cumulative distribution function used in logit analysis. In some specifications, we control for own returns and market returns for three time periods: $t-2, t-1$, and $t$. The vector of CEO characteristics is comprised of quadratic variables for age, tenure with the firm, and tenure as CEO. Also note the composite error term, $\alpha_{i}+\varepsilon_{i t}$, which contains possible permanent firm effects (which we explore below).

We have performed this estimation using a logit specification, although the results are similar when we use a probit or a linear probability model. One drawback of using our empirical approach is heteroscedasticity. We have run all regressions using White/Robust standard errors to control for this, but found no meaningful differences in significance levels.

Baseline logit results for the probability of CEO turnover conditional on observed firm and CEO characteristics are in Table $2 .{ }^{13}$ Columns 1 through 3 include only performance measures as controls. Higher own returns in period $t$ and $t-1$ consistently (and significantly) decrease the probability of turnover, while market returns generally increase the probability of turnover, though the coefficients are often insignificant. That is, conditional on market returns, when a firm performs poorly, the CEO is more likely to be changed.

Adding CEO characteristics (in columns 4 and 5) greatly increases the explanatory power of these regressions. As expected, older CEOs are much more likely to turn over, relative to younger CEOs. Additional years of tenure with the firm slightly decrease the probability of turnover, and at an increasing rate. Additional years as CEO have the opposite effect, increasing the probability of turnover at a decreasing rate.

To examine the role of unobservable firm characteristics in turnover, we include firm fixed effects, $\alpha_{i}$, in the last column of Table 2. Firm effects have not been widely explored in previous work. The motivation is to test whether own and market returns truly exhibit the effect described, or that the result is simply masking other unobserved variables attributable to firms. Controlling for firm fixed effects has little impact on the other

\footnotetext{
${ }^{13}$ Marginal effects are reported. $P$ values associated with robust variance estimates for the coefficients appear in parentheses.
} 
TABLE 2

Logit Results for Probability of CEO Turnover

\begin{tabular}{|c|c|c|c|c|c|}
\hline Independent variables & (1) & (2) & (3) & (4) & (5) \\
\hline (Own returns) & $\begin{array}{c}-0.047 * * * \\
(0.000)\end{array}$ & $\begin{array}{c}-0.051^{* * *} \\
(0.000)\end{array}$ & $\begin{array}{c}-0.053^{* * *} \\
(0.000)\end{array}$ & $\begin{array}{c}-0.040 * * * \\
(0.000)\end{array}$ & $\begin{array}{c}-0.028^{* * *} \\
(0.000)\end{array}$ \\
\hline$(\text { Own returns })_{t-1}$ & & $\begin{array}{c}-0.033^{* * *} \\
(0.006)\end{array}$ & $\begin{array}{c}-0.035^{* * *} \\
(0.004)\end{array}$ & $\begin{array}{c}-0.026^{* * *} \\
(0.009)\end{array}$ & $\begin{array}{c}-0.023^{* * *} \\
(0.001)\end{array}$ \\
\hline$(\text { Own returns })_{t-2}$ & & & $\begin{array}{c}-0.016 \\
(0.171)\end{array}$ & $\begin{array}{c}-0.011 \\
(0.236)\end{array}$ & $\begin{array}{c}-0.017 * * * \\
(0.003)\end{array}$ \\
\hline (Market returns) $)_{t}$ & $\begin{array}{c}0.032 \\
(0.113)\end{array}$ & $\begin{array}{c}0.032 \\
(0.112)\end{array}$ & $\begin{array}{c}0.031 \\
(0.144)\end{array}$ & $\begin{array}{c}0.021 \\
(0.218)\end{array}$ & $\begin{array}{c}0.022 * \\
(0.060)\end{array}$ \\
\hline$(\text { Market returns })_{t-1}$ & & $\begin{array}{c}-0.011 \\
(0.598)\end{array}$ & $\begin{array}{c}-0.010 \\
(0.607)\end{array}$ & $\begin{array}{c}-0.010 \\
(0.511)\end{array}$ & $\begin{array}{c}0.002 \\
(0.847)\end{array}$ \\
\hline (Market returns) $)_{t-2}$ & & & $\begin{array}{c}0.008 \\
(0.720)\end{array}$ & $\begin{array}{c}-0.004 \\
(0.800)\end{array}$ & $\begin{array}{c}0.003 \\
(0.792)\end{array}$ \\
\hline $\ln ($ market value) & & & & $\begin{array}{c}-0.003 \\
(0.211)\end{array}$ & $\begin{array}{c}-0.001 \\
(0.733)\end{array}$ \\
\hline Age & & & & $\begin{array}{l}0.045^{* * *} \\
(0.000)\end{array}$ & $\begin{array}{c}-0.051^{* * *} \\
(0.000)\end{array}$ \\
\hline $\mathrm{Age}^{2} / 1000$ & & & & $\begin{array}{c}-0.284^{* * *} \\
(0.000)\end{array}$ & $\begin{array}{l}0.534^{* * *} \\
(0.000)\end{array}$ \\
\hline Tenure with firm & & & & $\begin{array}{c}-0.002^{* *} \\
(0.042)\end{array}$ & $\begin{array}{c}-0.001 \\
(0.542)\end{array}$ \\
\hline (Tenure with firm) ${ }^{2} / 1000$ & & & & $\begin{array}{l}0.053^{* * *} \\
(0.005)\end{array}$ & $\begin{array}{l}0.045^{* * *} \\
(0.082)\end{array}$ \\
\hline Tenure as CEO & & & & $\begin{array}{l}0.004^{* * *} \\
(0.000)\end{array}$ & $\begin{array}{l}0.006^{* * *} \\
(0.000)\end{array}$ \\
\hline$(\text { Tenure as CEO) })^{2} / 1000$ & & & & $\begin{array}{c}-0.116^{* * *} \\
(0.001)\end{array}$ & $\begin{array}{c}-0.162^{* * *} \\
(0.000)\end{array}$ \\
\hline Firm indicators & & & & & Yes \\
\hline No. of observations & 8690 & 8690 & 8690 & 8690 & 8690 \\
\hline Pseudo $R^{2}$ & 0.0024 & 0.0042 & 0.0045 & 0.1102 & 0.2513 \\
\hline
\end{tabular}

A CEO change is when there is one CEO with the firm in year $t$ and another in year $t+1$.

Marginal effects are reported. $p$ values associated with robust variance estimates for coefficients appear in parentheses. All logits were run with a constant term.

***significant at the 1 percent level, **significant at the 5 percent level, *significant at the 10 percent level.

covariates, except for lessening the negative impact of contemporaneous own returns on CEO turnover. In sum, these results confirm the previously documented relationship between firm performance and executive turnover, but for a longer time period.

Are there Differences by Decade? It is interesting to consider whether the empirical results are consistent across time. To examine whether the determinants of CEO turnover have changed over time, we divide our data into three decades, and present these results in Table 3. The first three columns focus on 1970-1979. These columns include the same set of variables as 
TABLE 3

Logit Results for Probability of CEO Turnover by Decade

\begin{tabular}{|c|c|c|c|c|c|c|c|c|c|}
\hline & \multicolumn{3}{|c|}{$1970-1979$} & \multicolumn{3}{|c|}{$1980-1989$} & \multicolumn{3}{|c|}{$1990-1999$} \\
\hline & (1) & (2) & (3) & (4) & (5) & (6) & (7) & (8) & (9) \\
\hline (Own returns) & $\begin{array}{c}-0.085^{* * *} \\
(0.004)\end{array}$ & $\begin{array}{l}-0.082 * * * \\
(0.002)\end{array}$ & $\begin{array}{l}-0.048^{* * * *} \\
(0.000)\end{array}$ & $\begin{array}{c}-0.063^{* *} \\
(0.039)\end{array}$ & $\begin{array}{c}-0.055^{* *} \\
(0.038)\end{array}$ & $\begin{array}{c}-0.017^{*} \\
(0.074)\end{array}$ & $\begin{array}{c}-0.024 \\
(0.422)\end{array}$ & $\begin{array}{c}-0.011 \\
(0.715)\end{array}$ & $\begin{array}{c}0.001 \\
(0.817)\end{array}$ \\
\hline$(\text { Own returns })_{t-1}$ & $\begin{array}{c}-0.047 * \\
(0.067)\end{array}$ & $\begin{array}{c}-0.052^{* *} \\
(0.028)\end{array}$ & $\begin{array}{l}-0.043^{* * * *} \\
(0.001)\end{array}$ & $\begin{array}{c}-0.028 \\
(0.318)\end{array}$ & $\begin{array}{c}-0.031 \\
(0.208)\end{array}$ & $\begin{array}{c}-0.012 \\
(0.184)\end{array}$ & $\begin{array}{c}-0.043 \\
(0.178)\end{array}$ & $\begin{array}{c}-0.033 \\
(0.256)\end{array}$ & $\begin{array}{c}-0.0002 \\
(0.947)\end{array}$ \\
\hline$(\text { Own returns })_{t-2}$ & $\begin{array}{c}-0.002 \\
(0.923)\end{array}$ & $\begin{array}{c}-0.007 \\
(0.737)\end{array}$ & $\begin{array}{c}-0.017 \\
(0.110)\end{array}$ & $\begin{array}{c}-0.010 \\
(0.708)\end{array}$ & $\begin{array}{c}-0.017 \\
(0.455)\end{array}$ & $\begin{array}{c}-0.009 \\
(0.235)\end{array}$ & $\begin{array}{c}-0.044 \\
(0.154)\end{array}$ & $\begin{array}{c}-0.045 \\
(0.114)\end{array}$ & $\begin{array}{c}-0.005^{* *} \\
(0.026)\end{array}$ \\
\hline (Market returns) ${ }_{t}$ & $\begin{array}{c}0.007 \\
(0.888)\end{array}$ & $\begin{array}{c}0.036 \\
(0.385)\end{array}$ & $\begin{array}{c}0.026 \\
(0.163)\end{array}$ & $\begin{array}{c}0.095 \\
(0.327)\end{array}$ & $\begin{array}{c}0.143^{*} \\
(0.072)\end{array}$ & $\begin{array}{c}0.081^{* *} \\
(0.013)\end{array}$ & $\begin{array}{c}-0.027 \\
(0.691)\end{array}$ & $\begin{array}{c}-0.034 \\
(0.569)\end{array}$ & $\begin{array}{c}0.002 \\
(0.629)\end{array}$ \\
\hline$(\text { Market returns })_{t-1}$ & $\begin{array}{c}0.001 \\
(0.979)\end{array}$ & $\begin{array}{c}0.024 \\
(0.479)\end{array}$ & $\begin{array}{l}0.040^{* * *} \\
(0.006)\end{array}$ & $\begin{array}{c}-0.225^{* *} \\
(0.031)\end{array}$ & $\begin{array}{c}-0.112 \\
(0.189)\end{array}$ & $\begin{array}{c}-0.005 \\
(0.895)\end{array}$ & $\begin{array}{c}0.084 \\
(0.326)\end{array}$ & $\begin{array}{c}0.070 \\
(0.358)\end{array}$ & $\begin{array}{c}0.006 \\
(0.235)\end{array}$ \\
\hline (Market returns) $)_{t-2}$ & $\begin{array}{r}-0.064 \\
(0.163)\end{array}$ & $\begin{array}{c}-0.041 \\
(0.295)\end{array}$ & $\begin{array}{c}-0.026 \\
(0.149)\end{array}$ & $\begin{array}{c}-0.012 \\
(0.907)\end{array}$ & $\begin{array}{c}0.026 \\
(0.759)\end{array}$ & $\begin{array}{c}0.036 \\
(0.259)\end{array}$ & $\begin{array}{c}0.111 \\
(0.164)\end{array}$ & $\begin{array}{c}0.098 \\
(0.163)\end{array}$ & $\begin{array}{c}0.008 \\
(0.128)\end{array}$ \\
\hline $\ln ($ market value) & & $\begin{array}{c}-0.011^{*} \\
(0.057)\end{array}$ & $\begin{array}{c}-0.019 \\
(0.118)\end{array}$ & & $\begin{array}{c}-0.006 \\
(0.364)\end{array}$ & $\begin{array}{c}-0.008 \\
(0.495)\end{array}$ & & $\begin{array}{c}0.006 \\
(0.451)\end{array}$ & $\begin{array}{c}-0.0006 \\
(0.861)\end{array}$ \\
\hline CEO characteristics ${ }^{a}$ & & Yes & Yes & & Yes & Yes & & Yes & Yes \\
\hline Firm indicators & & & Yes & & & Yes & & & Yes \\
\hline No. of observations & 2457 & 2457 & 2457 & 2266 & 2266 & 2266 & 1652 & 1652 & 1652 \\
\hline Pseudo $R^{2}$ & 0.0074 & 0.1277 & 0.3577 & 0.0109 & 0.1226 & 0.3854 & 0.0038 & 0.0997 & 0.5148 \\
\hline
\end{tabular}

A CEO change is when there is one CEO with the firm in year $t$ and another in year $t+1$.

Marginal effects are reported. $p$ values associated with robust variance estimates for coefficients appear in parentheses. All logits were run with a constant term. ***significant at the 1 percent level, **significant at the 5 percent level, *significant at the 10 percent level.

${ }^{a} \mathrm{CEO}$ characteristics include age and its square, seniority with firm and its square, and seniority as CEO and its square. 
columns 4-6 in Table 2. For the 1970s, contemporaneous and one-year lagged own returns are significant determinants of turnover, even when firm fixed effects are added in column 3. These estimated coefficients can be further compared to those for 1980-1989 in columns 4-6 of Table 3. According to these results, own returns also significantly affect the probability of CEO turnover, but lagged returns do not. Thus far, it appears that performance in a CEO's last and second to the last years mattered most in the 1970s, while the performance in the last year mattered most in the 1980s. The last three columns of Table 3 contain the logit results for 1990-1999. ${ }^{14}$ Here own returns do not significantly decrease the probability of turnover.

Our findings are consistent with earlier studies on the relationship between share performance and top management turnover. Warner, Watts, and Wruck (1988) find that lower stock prices increase the probability of turnover using data from 1963 to 1978. Weisbach (1988) also uses data from the late 1970s and comes to a similar conclusion. Parrino (1997) finds a negative relationship between CEO turnover and firm performance for the 1970s and 1980s, although he does not differentiate between the decades as we do. It is only in the 1990s (which these authors did not study) that we do not find these relationships. Denis and Denis (1995) focus on forced turnover and find that its likelihood increases with negative share performance in the late 1980s. Mikkelson and Partch (1997) obtain a result particularly relevant to our work. They find that lower stock returns increase top management turnover in 1984 through 1988, but do not have a significant effect from 1989 to 1993 , which is consistent with our findings.

\section{The Relationship Between Management Turnover and Job Loss Announcements}

As described previously, increasing attention is being placed on the relationship between job loss and outcomes, not only for workers but also for firms. One important outcome for firms is what happens to the CEO around the time of job loss announcements. We examine the role of layoff announcements in predicting CEO turnover. If the board of directors view job loss announcements as "bad news," such announcements are likely to increase the probability of turnover. This coincides with the viewpoint that layoffs are a signal of impending problems or a CEO's last-ditch effort to improve firm profitability. If, on the other hand, reductions in force are seen as a way to

\footnotetext{
${ }^{14}$ Although our CEO data included the year 2000, the definition of the turnover variable required information for the following year. Thus, the last year in our data was excluded from these regressions.
} 
make the firm more efficient, they would be expected to decrease the likelihood of a CEO change. Indeed, information about the firm, the CEO, and the layoff(s) is likely to provide evidence about whether or not the board of directors considers layoffs to be welcome. As a similar example, Murphy and Zimmerman (1993) examine whether CEOs manipulate accounting variables such as advertising and capital expenditures in order to increase their own compensation. ${ }^{15}$ The authors find little evidence that CEOs who are about to leave exercise such discretion. Rather, their results suggest that changes in these variables are caused by declining firm performance. It is possible that layoffs are then not "discretionary," but instead occur mostly within struggling firms. The rest of this section is an investigation into whether job loss announcements benefit the CEO (suggesting that laying off workers is a positive self-interested decision), or lead to his or her dismissal.

Baseline Specifications. Table 4 presents results that provide some insight into the relationship between layoffs and executive turnover. These specifications mirror equation 1 , but add three new indicator variables for whether any layoff occurred for that firm within the years $t-2, t-1$, and $t$, respectively. Column 1 contains marginal effects from a logit specification involving only an indicator for whether there was a layoff in year $t$. This result suggests that a firm with at least one layoff is 2.5 percent more likely to have a new CEO in the following year, clearly supporting the notion that layoffs are, on average, "bad news" for the CEO and the board. Adding one lag of the job loss announcement indicator in column 2 does not change this result, nor does a two-period lag. This result remains significant through all specifications in Table 4.

Including firm performance, firm size, and CEO characteristics in column 5 decreases the marginal probability of turnover attributable to any layoff in year $t$ to 1.9 percent. The inclusion of firm-fixed effects (in column 6) further reduces the impact somewhat, yielding a 1.4 percent higher probability of turnover resulting from layoff announcements in year $t$. That is, even controlling for both observed and unobserved characteristics of firms and CEOs, layoff announcements are significantly related to management turnover.

We examine the robustness of this result in a few ways. First, if a layoff announcement that is made when the firm is experiencing poor performance has a greater effect on turnover, we would expect the coefficient on an interaction of the layoff indicator and firm returns to be positive. However, including interactions for three time periods yielded significant results in only one

${ }^{15}$ Healy (1985) examined accounting accruals and bonus contracts, and found that managers do respond to incentives in bonus contracts, manipulating variables in order to increase their compensation. 
TABLE 4

Logit Results for Probability of CEO Turnover Including Layoff Indicators

\begin{tabular}{|c|c|c|c|c|c|c|}
\hline Independent variables & (1) & (2) & (3) & (4) & (5) & (6) \\
\hline (Any layoff) & $\begin{array}{l}0.025^{* *} \\
(0.016)\end{array}$ & $\begin{array}{l}0.026^{* *} \\
(0.016)\end{array}$ & $\begin{array}{l}0.027 * * \\
(0.018)\end{array}$ & $\begin{array}{c}0.021^{*} \\
(0.054)\end{array}$ & $\begin{array}{c}0.019 * * \\
(0.027)\end{array}$ & $\begin{array}{l}0.014^{* *} \\
(0.035)\end{array}$ \\
\hline (Any layoff) $)_{t-1}$ & & $\begin{array}{c}-0.002 \\
(0.843)\end{array}$ & $\begin{array}{c}-0.001 \\
(0.925)\end{array}$ & $\begin{array}{c}0.0003 \\
(0.982)\end{array}$ & $\begin{array}{c}0.001 \\
(0.928)\end{array}$ & $\begin{array}{c}0.001 \\
(0.915)\end{array}$ \\
\hline (Any layoff) $)_{t-2}$ & & & $\begin{array}{c}-0.004 \\
(0.736)\end{array}$ & $\begin{array}{c}0.0005 \\
(0.965)\end{array}$ & $\begin{array}{c}0.002 \\
(0.794)\end{array}$ & $\begin{array}{l}0.003 \\
(0.621)\end{array}$ \\
\hline (Own returns) $)_{t}$ & & & & $\begin{array}{l}-0.051^{* * *} \\
(0.000)\end{array}$ & $\begin{array}{l}-0.039 * * * \\
(0.000)\end{array}$ & $\begin{array}{c}-0.027 * * \\
(0.000)\end{array}$ \\
\hline (Own returns) $)_{t-1}$ & & & & $\begin{array}{l}-0.033^{* * *} \\
(0.007)\end{array}$ & $\begin{array}{c}-0.024^{* *} \\
(0.015)\end{array}$ & $\begin{array}{l}-0.022^{* * *} \\
(0.001)\end{array}$ \\
\hline (Own returns $)_{t-2}$ & & & & $\begin{array}{c}-0.015 \\
(0.190)\end{array}$ & $\begin{array}{c}-0.010 \\
(0.267)\end{array}$ & $\begin{array}{l}-0.017 * * * \\
(0.003)\end{array}$ \\
\hline (Market returns) $)_{t}$ & & & & $\begin{array}{c}0.030 \\
(0.155)\end{array}$ & $\begin{array}{c}0.020 \\
(0.236)\end{array}$ & $\begin{array}{c}0.021^{*} \\
(0.074)\end{array}$ \\
\hline (Market returns) $)_{t-1}$ & & & & $\begin{array}{c}-0.009 \\
(0.658)\end{array}$ & $\begin{array}{c}-0.010 \\
(0.524)\end{array}$ & $\begin{array}{c}0.002 \\
(0.890)\end{array}$ \\
\hline (Market returns) $)_{t-2}$ & & & & $\begin{array}{c}0.009 \\
(0.682)\end{array}$ & $\begin{array}{c}-0.004 \\
(0.825)\end{array}$ & $\begin{array}{c}0.003 \\
(0.805)\end{array}$ \\
\hline $\ln ($ market value) & & & & $\begin{array}{c}-0.001 \\
(0.792)\end{array}$ & $\begin{array}{c}-0.004 \\
(0.128)\end{array}$ & $\begin{array}{c}-0.001 \\
(0.767)\end{array}$ \\
\hline Age & & & & & $\begin{array}{l}0.045^{* * *} \\
(0.000)\end{array}$ & $\begin{array}{l}-0.051^{* * *} \\
(0.000)\end{array}$ \\
\hline $\mathrm{Age}^{2} / 1000$ & & & & & $\begin{array}{l}-0.285^{* * *} \\
(0.000)\end{array}$ & $\begin{array}{l}0.533^{* * *} \\
(0.000)\end{array}$ \\
\hline Tenure with firm & & & & & $\begin{array}{l}-0.002 * * \\
(0.045)\end{array}$ & $\begin{array}{c}-0.001 \\
(0.578)\end{array}$ \\
\hline$(\text { Tenure with firm) })^{2} / 1000$ & & & & & $\begin{array}{l}0.052^{* * *} \\
(0.005)\end{array}$ & $\begin{array}{l}0.044^{* * *} \\
(0.091)\end{array}$ \\
\hline Tenure as CEO & & & & & $\begin{array}{l}0.004^{* * *} \\
(0.000)\end{array}$ & $\begin{array}{l}0.006^{* * *} \\
(0.000)\end{array}$ \\
\hline$(\text { Tenure as CEO) })^{2} / 1000$ & & & & & $\begin{array}{l}-0.118^{* * *} \\
(0.001)\end{array}$ & $\begin{array}{l}-0.162^{* * *} \\
(0.000)\end{array}$ \\
\hline Firm indicators & & & & & & Yes \\
\hline No. of observations & 8690 & 8690 & 8690 & 8690 & 8690 & 8690 \\
\hline Pseudo $R^{2}$ & 0.0009 & 0.0009 & 0.0009 & 0.0051 & 0.1111 & 0.2520 \\
\hline
\end{tabular}

A CEO change is when there is one CEO with the firm in year $t$ and another in year $t+1$.

Marginal effects are reported. $p$ values associated with robust variance estimates for coefficients appear in parentheses. All logits were run with a constant term.

***significant at the 1 percent level, **significant at the 5 percent level, *significant at the 10 percent level.

specification for the 1980s. Another factor could be future layoff announcements. To examine whether a CEO change is positively related to future layoffs, we added leading indicators for the presence of any job loss announcement to our regressions. In all specifications, the respective coefficients were insignificant, and did not affect the other variables in any meaningful way. 
Has the Relationship between Job Loss Announcements and CEO Turnover Changed over Time? Recent work by Farber and Hallock (2003) provides (limited) support for the view that layoffs were seen as "bad news" in the 1970s and 1980s, but have become relatively better news in the 1990s. Perhaps then layoffs have become less likely to induce CEO turnover in the 1990s. In an attempt to investigate whether this is true, we separately examine the three decades in our data. Table 5 contains logit results of CEO turnover on layoff indicators, firm size and performance, and CEO characteristics for three separate decades.

Layoffs did not consistently increase the probability of turnover in the 1970 s, as some point estimates are positive and others are negative (see columns 1-3). Columns 4-6 display the results for 1980-1989. In this case, a layoff 2 years in the past increases the probability of CEO turnover by 7.8 percent. This result is marginally significant, although markedly weaker with the inclusion of firm fixed effects in column 6. Furthermore, within firms, layoffs in the most recent year significantly decreased the likelihood of CEO turnover. The coefficient estimates for 1990-1999 are contained in the last three columns of Table 6. Job loss announcements this year and in the past do increase the likelihood of turnover across all specifications, but the coefficients are not significantly different from zero. Thus, we find evidence that job loss announcements impacted executive turnover in the 1970s and 1980s, but we find no evidence that layoffs were related to the likelihood of turnover in the 1990s.

\section{Possible Explanations for the CEO Turnover/Job Loss Relationship}

Now that we have documented the empirical relationship between job loss announcements and CEO turnover, we turn to considering some possible explanations for these findings. We focus on three possible reasons for the CEO turnover/job loss relationship in this section. The first is perhaps due to a change in the distribution of reasons for job loss announcements. The second concerns the response of the board of directors. The third, which we introduce here but concentrate on more heavily in section six, involves categorizing layoff announcements into "good news" or "bad news," based on the short-term stock price reactions to the announcements.

Changes in the Distribution of Reasons for Job Loss Announcements. Our results suggest that job loss announcements are associated with an increased likelihood of CEO turnover for the largest firms in the United 
TABLE 5

Logit Results for Probability of CEO Turnover Including Layoff Indicators by Decade

\begin{tabular}{|c|c|c|c|c|c|c|c|c|c|}
\hline & \multicolumn{3}{|c|}{$1970-1979$} & \multicolumn{3}{|c|}{$1980-1989$} & \multicolumn{3}{|c|}{ 1990-1999 } \\
\hline & (1) & (2) & (3) & (4) & (5) & (6) & (7) & (8) & (9) \\
\hline \multirow[t]{2}{*}{$(\text { Any layoff })_{t}$} & 0.030 & $0.038^{*}$ & 0.014 & 0.008 & 0.002 & $-0.013 * *$ & 0.027 & 0.046 & 0.002 \\
\hline & $(0.208)$ & $(0.070)$ & $(0.272)$ & $(0.728)$ & $(0.894)$ & $(0.044)$ & $(0.372)$ & $(0.111)$ & $(0.351)$ \\
\hline \multirow[t]{2}{*}{$(\text { Any layoff })_{t-1}$} & -0.007 & 0.010 & -0.004 & 0.003 & 0.002 & -0.007 & -0.003 & 0.002 & -0.002 \\
\hline & $(0.772)$ & $(0.661)$ & $(0.702)$ & $(0.915)$ & $(0.930)$ & $(0.391)$ & $(0.928)$ & $(0.502)$ & $(0.395)$ \\
\hline \multirow{2}{*}{$(\text { Any layoff })_{t-2}$} & $-0.051 * *$ & -0.029 & $-0.019 * *$ & $0.078 * * *$ & $0.075^{* * *}$ & $0.018^{*}$ & -0.042 & -0.030 & -0.003 \\
\hline & $(0.033)$ & $(0.176)$ & $(0.039)$ & $(0.003)$ & $(0.001)$ & $(0.069)$ & $(0.173)$ & $(0.398)$ & $(0.197)$ \\
\hline \multirow{2}{*}{ (Own returns) $)_{t}$} & $-0.083^{* * *}$ & $-0.080 * * *$ & $-0.047 * * *$ & $-0.061 * *$ & $-0.058 * *$ & $-0.020 * *$ & -0.021 & -0.008 & 0.001 \\
\hline & $(0.004)$ & $(0.002)$ & $(0.000)$ & $(0.034)$ & $(0.028)$ & $(0.025)$ & $(0.478)$ & $(0.842)$ & $(0.716)$ \\
\hline \multirow[t]{2}{*}{ (Own returns $)_{t-1}$} & -0.041 & $-0.049 * *$ & $-0.041 * * *$ & -0.025 & -0.032 & $-0.015^{*}$ & -0.038 & -0.028 & 0.0003 \\
\hline & $(0.107)$ & $(0.039)$ & $(0.001)$ & $(0.355)$ & $(0.183)$ & $(0.090)$ & $(0.223)$ & $(0.328)$ & $(0.924)$ \\
\hline \multirow[t]{2}{*}{$(\text { Own returns })_{t-2}$} & -0.002 & -0.007 & -0.016 & -0.003 & -0.010 & -0.009 & -0.043 & -0.043 & $-0.005^{* *}$ \\
\hline & $(0.953)$ & $(0.768)$ & $(0.126)$ & $(0.917)$ & $(0.643)$ & $(0.243)$ & $(0.165)$ & $(0.126)$ & $(0.029)$ \\
\hline \multirow[t]{2}{*}{ (Market returns) $)_{t}$} & 0.003 & 0.031 & 0.024 & 0.099 & $0.134 *$ & $0.082 * *$ & -0.025 & -0.032 & 0.003 \\
\hline & $(0.943)$ & $(0.457)$ & $(0.200)$ & $(0.301)$ & $(0.092)$ & $(0.012)$ & $(0.715)$ & $(0.483)$ & $(0.508)$ \\
\hline \multirow{2}{*}{ (Market returns) $)_{t-1}$} & 0.014 & 0.030 & $0.044 * * *$ & $-0.222 * *$ & -0.121 & -0.004 & 0.082 & 0.069 & 0.006 \\
\hline & $(0.699)$ & $(0.377)$ & $(0.002)$ & $(0.030)$ & $(0.149)$ & $(0.896)$ & $(0.337)$ & $(0.449)$ & $(0.192)$ \\
\hline \multirow[t]{2}{*}{ (Market returns) $)_{t-2}$} & -0.062 & -0.039 & -0.025 & -0.029 & 0.004 & 0.032 & 0.112 & 0.101 & 0.008 \\
\hline & $(0.177)$ & $(0.318)$ & $(0.152)$ & $(0.775)$ & $(0.964)$ & $(0.303)$ & $(0.161)$ & $(0.193)$ & $(0.114)$ \\
\hline \multirow[t]{2}{*}{$\ln ($ market value $)$} & -0.006 & $-0.012 *$ & -0.020 & $-0.019 * *$ & -0.009 & -0.008 & 0.0001 & 0.005 & -0.001 \\
\hline & $(0.346)$ & $(0.046)$ & $(0.089)$ & $(0.021)$ & $(0.180)$ & $(0.480)$ & $(0.992)$ & $(0.570)$ & $(0.701)$ \\
\hline CEO characteristics ${ }^{a}$ & & Yes & Yes & & Yes & Yes & & Yes & Yes \\
\hline Firm indicators & & & Yes & & & Yes & & & Yes \\
\hline No. of observations & 2457 & 2457 & 2457 & 2266 & 2266 & 2266 & 1652 & 1652 & 1652 \\
\hline Pseudo $R^{2}$ & 0.0107 & 0.1300 & 0.3606 & 0.0189 & 0.1294 & 0.3895 & 0.0052 & 0.1017 & 0.5173 \\
\hline
\end{tabular}

A CEO change is when there is one CEO with the firm in year $t$ and another in year $t+1$.

Marginal effects are reported. $p$ values associated with robust variance estimates for coefficients appear in parentheses. All logits were run with a constant term. ***significant at the 1 percent level, **significant at the 5 percent level, *significant at the 10 percent level.

${ }^{a} \mathrm{CEO}$ characteristics include age and its square, seniority with firm and its square, and seniority as CEO and its square. 
TABLE 6

Mean Layoff Characteristics

\begin{tabular}{|c|c|c|c|c|}
\hline & All years & $1970-1979$ & $1980-1989$ & 1990-1999 \\
\hline Number of layoffs during year & 2.033 & 2.201 & 2.032 & 1.792 \\
\hline \multirow{2}{*}{ Percent employees laid off } & $\begin{array}{c}(2.626) \\
0.057\end{array}$ & $\begin{array}{c}(2.860) \\
0.058\end{array}$ & $\begin{array}{c}(2.625) \\
0.056\end{array}$ & $\begin{array}{c}(2.240) \\
0.059\end{array}$ \\
\hline & $(0.126)$ & $(0.155)$ & $(0.121)$ & $(0.076)$ \\
\hline \multirow[t]{2}{*}{ Percent of annual layoffs that are temporary } & 0.179 & 0.275 & 0.156 & 0.073 \\
\hline & $(0.348)$ & $(0.406)$ & $(0.321)$ & $(0.243)$ \\
\hline \multirow[t]{2}{*}{ Percent of annual layoffs for reorganization } & 0.261 & 0.121 & 0.194 & 0.320 \\
\hline & $(0.440)$ & $(0.297)$ & $(0.370)$ & $(0.441)$ \\
\hline \multirow[t]{2}{*}{ Percent of annual layoffs for cost control } & 0.209 & 0.186 & 0.214 & 0.236 \\
\hline & $(0.375)$ & $(0.357)$ & $(0.382)$ & $(0.399)$ \\
\hline \multirow[t]{2}{*}{ Percent of annual layoffs for plant closing } & 0.072 & 0.082 & 0.063 & 0.071 \\
\hline & $(0.233)$ & $(0.246)$ & $(0.220)$ & $(0.231)$ \\
\hline \multirow[t]{2}{*}{ Percent of annual layoffs for low demand } & 0.374 & 0.424 & 0.398 & 0.268 \\
\hline & $(0.444)$ & $(0.449)$ & $(0.450)$ & $(0.413)$ \\
\hline \multirow{2}{*}{ Weighted returns at layoff ${ }^{a}$} & -0.003 & -0.005 & -0.004 & 0.001 \\
\hline & $(0.039)$ & $(0.037)$ & $(0.036)$ & $(0.045)$ \\
\hline Number of observations & 1129 & 423 & 412 & 294 \\
\hline
\end{tabular}

Standard deviations in parentheses.

${ }^{a}$ Average excess returns for [1,1] 3-day window around layoff, weighted by inverse variance.

States. In an effort to explain this relationship, we examine the characteristics of these layoffs, as reported in the Wall Street Journal abstracts. Unfortunately, this source does not provide detailed information for all announcements, so we read the full-length articles to gain more detailed information. Table 6 lists mean layoff characteristics for all firm-year observations where such information was provided. The percent of employees laid off is simply the number of employees laid off in a given year (perhaps for multiple layoffs) divided by the total number of employees at the firm (collected from COMPUSTAT). On average, 5.7 percent of employees are laid off in a typical year, with minimal variation over time. The proportion of layoffs that are intended to be temporary has changed over time, though. It appears that 27.5 percent of job loss announcements in the 1970s were planned as temporary, as compared to only 7.3 percent in the early 1990s. Table 7 considers whether the percent of employees laid off affects CEO turnover. In column 1, there appears to be a strong effect; firms that lay off a larger fraction of their workers have a higher probability of removing the CEO. This result does not persist when firm fixed effects are considered in column 5, however.

In Table 6, we also see the distribution of job loss announcements across the main stated reasons: reorganization, cost control, plant closing, and low 
TABLE 7

Logit Results for Probability of CEO Turnover Including Layoff Characteristics

\begin{tabular}{|c|c|c|c|c|c|}
\hline Independent variables & (1) & (2) & (3) & (4) & (5) \\
\hline$(\text { Any layoff })_{t}$ & $\begin{array}{c}0.009 \\
(0.319)\end{array}$ & $\begin{array}{c}0.014 \\
(0.146)\end{array}$ & $\begin{array}{c}0.016^{*} \\
(0.061)\end{array}$ & $\begin{array}{c}0.012 \\
(0.228)\end{array}$ & $\begin{array}{c}0.011 \\
(0.194)\end{array}$ \\
\hline$(\text { Any layoff })_{t-1}$ & $\begin{array}{c}0.0004 \\
(0.967)\end{array}$ & $\begin{array}{c}0.001 \\
(0.913)\end{array}$ & $\begin{array}{c}-0.0001 \\
(0.987)\end{array}$ & $\begin{array}{l}0.0013 \\
(0.882)\end{array}$ & $\begin{array}{c}0.001 \\
(0.826)\end{array}$ \\
\hline$(\text { Any layoff })_{t-2}$ & $\begin{array}{c}0.001 \\
(0.874)\end{array}$ & $\begin{array}{c}0.002 \\
(0.859)\end{array}$ & $\begin{array}{c}0.002 \\
(0.820)\end{array}$ & $\begin{array}{c}0.003 \\
(0.753)\end{array}$ & $\begin{array}{c}0.004 \\
(0.564)\end{array}$ \\
\hline Percent employees laid off & $\begin{array}{l}0.098^{* *} \\
(0.025)\end{array}$ & & & $\begin{array}{c}0.072 \\
(0.159)\end{array}$ & $\begin{array}{c}0.036 \\
(0.552)\end{array}$ \\
\hline Percent employees missing & $\begin{array}{c}0.030 \\
(0.216)\end{array}$ & & & $\begin{array}{c}0.019 \\
(0.382)\end{array}$ & $\begin{array}{c}0.020 \\
(0.188)\end{array}$ \\
\hline Number of layoffs in year & & $\begin{array}{c}0.001 \\
(0.561)\end{array}$ & & $\begin{array}{c}-0.003 \\
(0.345)\end{array}$ & $\begin{array}{c}-0.002 \\
(0.510)\end{array}$ \\
\hline Wtd returns*(any layoff $)_{t}^{a}$ & & $\begin{array}{c}-0.348^{*} \\
(0.075)\end{array}$ & & $\begin{array}{c}-0.287^{*} \\
(0.092)\end{array}$ & $\begin{array}{c}-0.240^{*} \\
(0.069)\end{array}$ \\
\hline Wtd returns*(any layoff $)_{t-1}$ & & $\begin{array}{c}0.316 \\
(0.114)\end{array}$ & & $\begin{array}{c}0.277 \\
(0.124)\end{array}$ & $\begin{array}{c}0.152 \\
(0.290)\end{array}$ \\
\hline Wtd returns*(any layoff $)_{t-2}$ & & $\begin{array}{c}-0.112 \\
(0.614)\end{array}$ & & $\begin{array}{c}-0.068 \\
(0.723)\end{array}$ & $\begin{array}{c}-0.094 \\
(0.511)\end{array}$ \\
\hline SIC codes & & & Yes & Yes & \\
\hline Firm indicators & & & & & Yes \\
\hline No. of observations & 8690 & 8690 & 8690 & 8690 & 8690 \\
\hline Pseudo $R^{2}$ & 0.1119 & 0.1121 & 0.1496 & 0.1509 & 0.2531 \\
\hline
\end{tabular}

A CEO change is when there is one CEO with the firm in year $t$ and another in year $t+1$.

Marginal effects are reported. $p$ values associated with robust variance estimates for coefficients appear in parentheses. All logits were run with a constant term.

Additional covariates are as in Table 5 column 5; returns, $\ln$ (market value), and CEO characteristics are included.

***significant at the 1 percent level, **significant at the 5 percent level, *significant at the 10 percent level.

${ }^{a} \mathrm{Wtd}$ returns are average excess returns for [1,1] 3-day window around layoff, weighted by inverse variance.

demand. ${ }^{16}$ Plant closings and low demand seem to signal serious difficulties for the firm, while reorganization and cost control appear more positive, at least at face value. In fact, according to the popular press and many interviews with senior managers, layoffs have become "good news" in recent years, as they signify increased efficiency (Hallock, 2003). Apparently reflecting this sentiment, the proportion of job loss announcements attributable to reorganization and cost control has increased over time. ${ }^{17}$ Reorganization is the stated reason for 12.1 percent of layoffs in the $1970 \mathrm{~s}$, but jumps to 32.0 percent of those in the 1990s. Layoffs categorized for cost control reasons have increased from 18.6 to 23.6 percent over the same time period. As expected, the proportion of layoffs attributable to plant closings and low demand has decreased from

\footnotetext{
${ }^{16}$ These were originally collected as 18 different reported reasons, and we have combined many of them for simplicity.

${ }^{17}$ Section six investigates share price reactions to these layoff announcements.
} 
the 1970s to the 1990s. This suggests that over time job loss announcements have had the appearance of being more positive for firms, and thus are perhaps less likely to adversely affect top management. In that case, our earlier result that layoffs are related to CEO turnover in the future seems puzzling, but potential explanations are possible. These are explored in additional logit analyses (not reported in the tables). The stated reasons for layoffs do not seem to have a significant influence on CEO turnover probabilities.

The Boards' Response to Job Loss Announcements. Our results suggest that layoffs are significantly related to CEO changes, but that the actual changes may happen slowly, as we found for the 1980s. Some possible reasons for this do not directly involve layoff announcements. For instance, it is possible that CEOs who are entrenched in their firms are less likely to leave than regular workers? CEOs who are founders are a prime example of this, as are CEOs who own a large proportion of the company's stock. ${ }^{18}$ In either scenario, the board would have a fair amount of difficulty removing a CEO quickly. ${ }^{19}$ An additional possibility is that some new CEOs have been hired in order to make the firm more efficient by laying off employees and taking other cost-cutting measures. Thus, new CEOs (those in their first two years of tenure) may be particularly less likely to turnover when they announce mass layoffs. The inclusion of interaction terms for new CEOs and layoff announcements yielded consistently insignificant results, and did not impact the other parameters. A similar argument pertains to CEOs hired from outside the firm. Additional variables to measure this potential impact contribute one interesting result: in some specifications, CEOs hired from the outside were more likely to turnover due to layoffs in the 1970s, and the opposite was true for some 1980s specifications. This provides some evidence that, starting in the 1980s, CEOs may have been hired into the firm in order to generate layoffs and make the firm more efficient.

Stock Returns. Another explanation is that job loss announcements do not signal potential profitability as clearly as stock returns do. It stands to reason that a fair amount of time would pass between the rank-and-file being laid off and the CEO being dismissed. Perhaps in these circumstances, firms require several years to find a new $\mathrm{CEO}$ who can turn the company around. Nonetheless, the previous discussion of stated layoff reasons provides

${ }^{18}$ Unfortunately, our data do not include these characteristics, but further work could examine the role of these factors in CEO turnover for this time period.

${ }^{19}$ It would also be interesting to study the career patterns of top managers, and see whether this is related to layoffs. Two papers that have recently studied career patterns are Fee and Hadlock (2004) and Hayes, Oyer, and Shaefer (2003). 
another possible explanation. If layoffs have the expressed purpose of reorganization or controlling costs, the initial response of the board is likely to be favorable. Then, if time passes and performance does not significantly improve, the board will look to replace top management. Our results appear to be consistent with this explanation. We now turn to a more detailed examination of the stock price reaction to job loss announcements and the subsequent effect on CEO turnover.

\section{Does the Short-term Stock Price Reaction to Job Loss Announcements Help to Explain CEO Turnover?}

Determining whether a job loss announcement is good news or bad news for the firm is particularly difficult, even with the wealth of data we have. It seems reasonable to investigate whether the short-term stock price reaction to job loss announcements influences the probability of CEO turnover as stock prices are such an important metric in firms. For example, perhaps firms that announce layoffs that are perceived as "good news" (e.g. a very clever reorganization) are likely to retain their CEOs because of the good work that they have done. On the other hand, CEOs that authorize layoffs that are perceived as "bad news" may subsequently lose their jobs.

In this section, we investigate this idea by augmenting our typical logit specifications (from Tables 4 and 5) by including an interaction term between weighted 3-day stock price reactions to job loss announcements over the year and the layoff indicators described previously. ${ }^{20}$ First, we will describe our methods for estimating stock price reactions.

The methods we use here are widely known in the corporate finance field (e.g. Fama et al., 1969, and Cambell, Lo, and MacKinlay, 1997), and we only outline the method here. Clearly defining event dates is certainly crucial, and we define an event as happening on the day it was reported in the Wall Street Journal.

Let $t$ index time in trading days, $e$ indicate the day of the layoff announcement, and $f$ index firms. Then using value-weighted return data from the CRSP at the University of Chicago, $\mathrm{R}_{f t}$, the daily return for firm $f$, is regressed on $\mathrm{R}_{m t}$, the value weighted market return on day $t$. This regression,

$$
\mathbf{R}_{f t}=\alpha_{f}+\beta_{f} \mathbf{R}_{m t}+\varepsilon_{f t},
$$

\footnotetext{
${ }^{20}$ Because firms can make multiple announcements in a given year, we have taken the weighted average of all three-day returns for the firms in the year where the weights are the inverse of the variance of the returns (see succeeding discussions).
} 
is estimated from day $e-60$ to day $e-30$. Then for the days around day $e$, we calculate the daily abnormal or excess return,

$$
\mathrm{ER}_{f t}=R_{f t}-\left(\hat{\alpha}_{f}+\hat{\beta}_{f} \mathrm{R}_{m t}\right) \text {, }
$$

where $\hat{\alpha}_{f}$ and $\hat{\beta}_{f}$ are estimated in equation 2 . The excess return can be considered the part of the movement in the stock return of firm $f$ that is not correlated with the overall market movements, and therefore reflects unexpected firm-specific factors. The three-day cumulative announcements that we use are computed by summing the returns on days $e-1, e$, and $e+1$. We then generate weighted averages of these by firm-year, using the inverse of the variance as weights. Thus, each firm, in each year, has a single weighted share price reaction value.

It is clear from Table 7 that the stock price reaction to employee layoffs impacts CEO turnover. That is, there is a strong and significant effect such that higher stock price reactions to layoff announcements yield lower probabilities of CEO turnover. This effect persists in three distinct cases: across firms and industries, within industries, and within firms. Table 8 shows that much of this effect is to the result of a substantial relationship in the 1970s. Within firms, higher returns are associated with significantly lower turnover, while the relationship across firms is positive, suggesting that layoffs with more positive reactions induce more CEO turnover one year in the future. On the other hand, the effects of stock price reactions in the 1980s and 1990s are rarely significantly different from zero. In the 1980s, the previously estimated positive effect of layoff announcements two years ago remains, and some additional layoff characteristics are also significant. For instance, within firms, more announcements and larger layoffs imply lower turnover. Table 8 also displays some evidence counter to the conventional wisdom that job loss announcements were relatively "good" news in the 1990s. Specifically, the mere presence of layoffs did not significantly (negatively) impact turnover, and CEOs who laid off more employees were relatively more likely to leave the firm.

\section{Concluding Comments}

The main goal of this work is to investigate the basic relationship between job loss announcements and turnover of top management. It begins by documenting that job loss announcements seem to be related to certain CEO and firm characteristics. For example, in the cross section, it appears that CEOs are more likely to turnover, and that larger firms (by many accounts) experience more job loss announcements. The paper goes on to 
TABLE 8

Logit Results for Probability of CEO Turnover Including Layoff Characteristics by Decade

\begin{tabular}{|c|c|c|c|c|c|c|c|c|c|}
\hline \multirow[b]{2}{*}{ Independent variables } & \multicolumn{3}{|c|}{$1970-1979$} & \multicolumn{3}{|c|}{$1980-1989$} & \multicolumn{3}{|c|}{ 1990-1999 } \\
\hline & (1) & (2) & (3) & (4) & (5) & (6) & (7) & (8) & (9) \\
\hline$(\text { Any layoff })_{t}$ & $\begin{array}{c}0.014 \\
(0.568)\end{array}$ & $\begin{array}{c}0.007 \\
(0.769)\end{array}$ & $\begin{array}{c}0.002 \\
(0.908)\end{array}$ & $\begin{array}{c}0.028 \\
(0.283)\end{array}$ & $\begin{array}{c}0.042 * \\
(0.078)\end{array}$ & $\begin{array}{c}0.012 \\
(0.285)\end{array}$ & $\begin{array}{c}0.010 \\
(0.759)\end{array}$ & $\begin{array}{c}0.005 \\
(0.878)\end{array}$ & $\begin{array}{c}0.003 \\
(0.727)\end{array}$ \\
\hline$(\text { Any layoff })_{t-1}$ & $\begin{array}{c}0.016 \\
(0.483)\end{array}$ & $\begin{array}{c}0.011 \\
(0.618)\end{array}$ & $\begin{array}{c}-0.001 \\
(0.926)\end{array}$ & $\begin{array}{c}0.009 \\
(0.649)\end{array}$ & $\begin{array}{c}0.0004 \\
(0.983)\end{array}$ & $\begin{array}{c}-0.004 \\
(0.659)\end{array}$ & $\begin{array}{c}-0.002 \\
(0.950)\end{array}$ & $\begin{array}{c}-0.004 \\
(0.869)\end{array}$ & $\begin{array}{c}-0.003 \\
(0.296)\end{array}$ \\
\hline$(\text { Any layoff })_{t-2}$ & $\begin{array}{c}-0.033 \\
(0.140)\end{array}$ & $\begin{array}{c}-0.028 \\
(0.171)\end{array}$ & $\begin{array}{c}-0.020 * * \\
(0.028)\end{array}$ & $\begin{array}{l}0.080 * * * \\
(0.001)\end{array}$ & $\begin{array}{l}0.053^{* *} \\
(0.009)\end{array}$ & $\begin{array}{c}0.017^{*} \\
(0.066)\end{array}$ & $\begin{array}{c}-0.032 \\
(0.261)\end{array}$ & $\begin{array}{c}-0.037 \\
(0.168)\end{array}$ & $\begin{array}{c}-0.003 \\
(0.200)\end{array}$ \\
\hline Percent employees laid off & $\begin{array}{c}0.085 \\
(0.320)\end{array}$ & $\begin{array}{c}0.118 \\
(0.215)\end{array}$ & $\begin{array}{c}0.107 \\
(0.184)\end{array}$ & $\begin{array}{c}0.041 \\
(0.717)\end{array}$ & $\begin{array}{c}-0.088 \\
(0.313)\end{array}$ & $\begin{array}{c}-0.127^{* *} \\
(0.017)\end{array}$ & $\begin{array}{c}0.496^{*} \\
(0.057)\end{array}$ & $\begin{array}{c}0.564^{*} \\
(0.065)\end{array}$ & $\begin{array}{c}0.035 \\
(0.174)\end{array}$ \\
\hline Percent employees missing & $\begin{array}{c}0.082 \\
(0.139)\end{array}$ & $\begin{array}{c}0.070 \\
(0.162)\end{array}$ & $\begin{array}{c}0.036 \\
(0.172)\end{array}$ & $\begin{array}{c}0.001 \\
(0.990)\end{array}$ & $\begin{array}{c}-0.028 \\
(0.387)\end{array}$ & $\begin{array}{c}-0.008 \\
(0.501)\end{array}$ & $\begin{array}{c}0.032 \\
(0.749)\end{array}$ & $\begin{array}{c}0.007 \\
(0.950)\end{array}$ & $\begin{array}{c}0.003 \\
(0.798)\end{array}$ \\
\hline Number of layoffs in year & $\begin{array}{c}0.001 \\
(0.786)\end{array}$ & $\begin{array}{c}0.003 \\
(0.611)\end{array}$ & $\begin{array}{c}-0.001 \\
(0.788)\end{array}$ & $\begin{array}{c}-0.016^{*} \\
(0.067)\end{array}$ & $\begin{array}{l}-0.027^{* * *} \\
(0.006)\end{array}$ & $\begin{array}{l}-0.013^{* * *} \\
(0.004)\end{array}$ & $\begin{array}{c}-0.001 \\
(0.941)\end{array}$ & $\begin{array}{c}-0.005 \\
(0.664)\end{array}$ & $\begin{array}{c}-0.001 \\
(0.218)\end{array}$ \\
\hline Wtd returns*(any layoff) ${ }_{t}^{a}$ & $\begin{array}{c}-0.544 \\
(0.207)\end{array}$ & $\begin{array}{c}-0.596 \\
(0.116)\end{array}$ & $\begin{array}{c}-0.547^{* *} \\
(0.023)\end{array}$ & $\begin{array}{c}-0.111 \\
(0.826)\end{array}$ & $\begin{array}{c}-0.016 \\
(0.969)\end{array}$ & $\begin{array}{c}0.070 \\
(0.737)\end{array}$ & $\begin{array}{c}-0.303 \\
(0.530)\end{array}$ & $\begin{array}{c}-0.203 \\
(0.604)\end{array}$ & $\begin{array}{c}0.031 \\
(0.731)\end{array}$ \\
\hline Wtd returns*(any layoff) $)_{t-1}$ & $\begin{array}{l}0.981^{* *} \\
(0.031)\end{array}$ & $\begin{array}{c}0.811^{*} \\
(0.052)\end{array}$ & $\begin{array}{c}0.260 \\
(0.315)\end{array}$ & $\begin{array}{c}0.634 \\
(0.195)\end{array}$ & $\begin{array}{c}0.799 * \\
(0.050)\end{array}$ & $\begin{array}{c}0.438^{*} \\
(0.090)\end{array}$ & $\begin{array}{c}0.724 \\
(0.234)\end{array}$ & $\begin{array}{c}0.272 \\
(0.642)\end{array}$ & $\begin{array}{c}0.008 \\
(0.755)\end{array}$ \\
\hline Wtd returns*(any layoff $)_{t-2}$ & $\begin{array}{c}0.207 \\
(0.721)\end{array}$ & $\begin{array}{c}0.086 \\
(0.863)\end{array}$ & $\begin{array}{c}-0.090 \\
(0.748)\end{array}$ & $\begin{array}{c}0.028 \\
(0.956)\end{array}$ & $\begin{array}{c}0.093 \\
(0.830)\end{array}$ & $\begin{array}{c}0.113 \\
(0.599)\end{array}$ & $\begin{array}{c}0.164 \\
(0.856)\end{array}$ & $\begin{array}{c}-0.197 \\
(0.791)\end{array}$ & $\begin{array}{c}0.0004 \\
(0.968)\end{array}$ \\
\hline SIC codes & & Yes & & & Yes & & & Yes & \\
\hline Firm indicators & & & Yes & & & Yes & & & Yes \\
\hline No. of observations & 2457 & 2457 & 2457 & 2266 & 2266 & 2266 & 1652 & 1652 & 1652 \\
\hline Pseudo $R^{2}$ & 0.1336 & 0.1951 & 0.3657 & 0.1316 & 0.2063 & 0.3998 & 0.1049 & 0.1905 & 0.5194 \\
\hline
\end{tabular}

A CEO change is when there is one CEO with the firm in year $t$ and another in year $t+1$.

Marginal effects are reported. $p$ values associated with robust variance estimates for coefficients appear in parentheses. All logits were run with a constant term.

Additional covariates are as in Table 5 column 5 ; returns, $\ln$ (market value), and CEO characteristics are included.

$* * *$ significant at the 1 percent level, $* *$ significant at the 5 percent level, *significant at the 10 percent level.

${ }^{a} \mathrm{Wtd}$ returns are average excess returns for [1,1] 3-day window around layoff, weighted by inverse variance. 
investigate the relationship between firm and market performance and CEO turnover. Consistent with a host of previous authors and with simple principal-agent models, we find that own stock price performance is negatively related to management turnover and that market performance is positively related. We also document that the relationship between returns and turnover varies over time.

We then investigated the relationship between announcements of job loss and management turnover and found mixed results, suggesting that CEOs are likely to turnover some time after their firm announces a layoff. We explored several dynamic specifications including leads and lags of performance and the layoff indicator variables, and this result seems robust.

The fact that there is a relationship between mass layoff announcements and CEO turnover is interesting in light of Hallock's (1998) finding that job loss announcements did not lead to higher CEO pay. Although he used data from only the late 1980s through the mid-1990s, he found that, in the cross section, firms making layoff announcements paid their managers more. This result did not remain when he controlled for observed and unobserved CEO and firm characteristics. In our case, the mass layoff/CEO turnover result seems to be robust to a similar careful empirical test. More importantly, neither study supports the notion that layoffs have positive effects on CEOs.

We attempted to investigate several possible explanations for this relationship. It seems that the most promising is the "share price reaction" analysis. We have strong evidence that layoffs that are associated with negative stock price reactions are much more likely to lead to CEO turnover than layoffs associated with positive stock price reactions, especially earlier in the sample.

We would recommend several directions for future work in this area. It might be useful to further investigate the characteristics of the job loss announcements. We also think it is important to more deeply investigate "corporate control" issues, such as whether entrenchment of the board may protect the CEO from being removed in the face of large job cuts in firms. In addition, although we control for market performance and year effects, it would be useful to examine whether the business cycle has a direct impact on our findings. We hope that our work in a useful first-step in this area.

\section{REFERENCES}

Antle, Rick, and Abbie Smith. 1986. "An Empirical Investigation of the Relative Performance Evaluation of Corporate Executives." Journal of Accounting Research 24(Spring):1-39.

Baumol, William J., Alan S. Blinder, and Edward N. Wolff. 2003. Downsizing in America: Reality, Causes, and Consequences. New York, NY: Russell Sage Foundation.

Berle, Adolf, and Gardiner Means. 1932. The Modern Corporation and Private Property. New York, NY: Macmillan. 
Campbell, John Y., Andrew W. Lo, and A. Craig MacKinlay. 1997. The Econometrics of Financial Markets. Princeton, NY: Princeton University Press.

Cappelli, Peter. 2000. "Examining the Incidence of Downsizing and its Effect on Establishment Performance." In On the Job: Is Long-Term Employment a Thing of the Past? edited by David Neumark, pp. 463-516, New York, NY: Russell Sage Foundation.

Conyon, Martin J. 1998. "Directors' Pay and Turnover: An Application to a Sample of Large UK Firms." Oxford Bulletin of Economics and Statistics 60(November):485-507.

Coughlan, Anne T., and Ronald M. Schmidt. 1985. "Executive Compensation, Management Turnover, and Firm Performance: An Empirical Investigation." Journal of Accounting and Economics 7(April):43-66.

Dial, Jay, and Kerin J. Murphy. 1995. "Incentives, Downsizing, and Value Creation at General Dynamics." Journal of Financial Economics 37(March):261-314.

Denis, David J., and Diane K. Denis. 1995. "Performance Changes Following Top Management Dismissals." Journal of Finance 50(September):1029-57.

Fama, Eugene, Lawrence Fisher, Michael Jensen, and Richard Roll. 1969. "The Adjustment of Stock Price to New Information." International Economic Review 10(February):1-21.

Farber, Henry S. 2003 "Job Loss in the United States, 1981-2001." Unpublished Paper. Princeton University. - and Kevin F. Hallock. 1999. "Capital Markets and Job Loss: Evidence from North America." Wirtschafts Politische Blatter 36(December):573-577.

. 2004. "The Changing Relationship Between Job Loss Announcements and Stock Prices: 19701999." Unpublished paper. Princeton University and University of Illinois.

Fee, C. Edward, and Charles Hadlock. 2004. "Management Turnover Across the Corporate Hierarchy." Unpublished paper. Michigan State University.

Forbes. 1970-1991. Annual Compensation survey issues.

Gibbons, Robert, and Kevin J. Murphy. 1990. "Relative Performance Evaluation for Chief Executive Officers." Industrial and Labor Relations Review 43(February):30s-51s.

Gilson, Stuart. 1989. "Management Turnover and Financial Distress." Journal of Financial Economics 25(December):241-62.

Hadlock, Charles J., and Gerald B. Lumer. 1997. "Compensation, Turnover, and Top Management Incentives: Historical Evidence.” Journal of Business 70(April):153-187.

Hall, Brian J., and Jeffrey B. Liebman. 1998. “Are CEOs Really Paid Like Bureaucrats?” Quarterly Journal of Economics 113(August):653-91.

Hallock, Kevin F. 1998. "Layoffs, Top Executive Pay, and Firm Performance." American Economic Review 88(September):711-23.

—. 2003. "A Descriptive Analysis of Layoffs in Large U.S. Firms Using Archival and Interview Data: 1970-2002." Unpublished paper. University of Illinois.

and Kevin J. Murphy. 1999. "Introduction." In The Economics of Executive Compensation, edited by Kevin F. Hallock and Kevin J. Murphy, pp. ix-xxvii, Cheltenham UK, and Northampton, MA: Edward Elgar Publishing.

Hayes, Rachel M., Paul Oyer, and Scott Schaefer. 2003. "Coworker-Specific Investments and Stability of Top Management Teams," Unpublished paper. University of Chicago, Stanford University, and Northwestern University.

Healy, Paul M. 1985. "The Effect of Bonus Schemes on Accounting Decisions," Journal of Accounting and Economics 7(April):85-107.

Huson, Mark, Robert Parrino, and Laura Sparks. 2001. "The Effectiveness of Internal Monitoring Mechanisms: Evidence from CEO Turnover Between 1971 and 1994”. Journal of Finance $\operatorname{LVI}(6)$.

Jensen, Michael C., and William H. Meckling. 1976. "Theory of the Firm: Managerial Behaviour, Agency Costs, and Ownership Structure." Journal of Financial Economics 3(October):305-60.

- and Kevin J. Murphy. 1990. "Performance Pay and Top-Management Incentives." Journal of Political Economy 98(April):225-64.

Kaplan, Steven. 1994a. "Top Executive Rewards and Firm Performance: A Comparison of Japan and the United States." Journal of Political Economy 102(June):510-46. 
. 1994b. "Top Executives, Turnover, and Firm Performance in Germany." Journal of Law, Economics, and Organization 10(April):142-59.

Mikkelson, Wayne H., and M. Megan Partch. 1997. "The Decline of Takeovers and Disciplinary Managerial Turnover." Journal of Financial Economics 44(May):205-28.

Murphy, Kevin J., and Jerold L. Zimmerman. 1993. "Financial Performance Surrounding CEO Turnover." Journal of Accounting and Economics 16(January-April-July):273-315.

Parrino, Robert. 1997. "CEO Turnover and Outside Succession: A Cross-Sectional Analysis." Journal of Financial Economics 46(November):165-97.

Thompson, Robert B. II, Chris Olsen, and J. Richard Dietrich. 1987. "Attributes of News about Firms: An Analysis of Firm-Specific News Reported in the Wall Street Journal Index." Journal of Accounting Research 25(Autumn):245-74.

Vancil, Richard. 1987. Passing the Baton: Managing the Process of CEO Succession. Boston, MA: Harvard Business School Press.

Wall Street Journal Index. 1967-1999. New York, NY: Dow Jones and Company.

Warner, Jerold B., Ross L. Watts, and Karen H. Wruck. 1988. "Stock Prices and Top Management Changes." Journal of Financial Economics 20(January/March):461-92.

Weisbach, Michael S. 1988. "Outside Directors and CEO Turnover." Journal of Financial Economics 20(January/March):431-60. 
Copyright of Industrial Relations is the property of Blackwell Publishing Limited and its content may not be copied or emailed to multiple sites or posted to a listserv without the copyright holder's express written permission. However, users may print, download, or email articles for individual use. 